prisoners consists of 4,212 individuals; and foreign, foreign born, negro and negroid criminals were treated on the same scale. Dr. Aleš Hrdlička has been moved by the discussion to revive and review material which he collected more than forty years ago, when the question was previously under discussion (J. Criminal Psychopathology, 1, 2 ; 1939). In 189799, the New York Juvenile Asylum contained 1,000 inmates of both sexes, 5-16 years of age, of whom 77 were criminal or vicious, and 61 were the offspring of criminal, insane, intemperate or dissolute parents. Anthropometric measurement of each child in the institution showed that the transgressors could not be separated physically from the remainder, or probably from similar classes outside. Apart from their conduct they could not have been recognized as criminal. Of the children of the intemperate and other undesirables, however, it was found that almost 60 per cent were "inferior in their principal measurements to the general averages of the corresponding class of the asylum children", or subnormal. Dr. Hrdlička's conclusion, therefore, is that it is "hopeless to expect that anthropometry and physical examination can ever aid in this detection".

\section{Malting Barley}

THE agricultural data derived from five conferences on malting barley held at Rothamsted Experimental Station in the years 1934-38 have been described and discussed by H. V. Garner and J. W. Weil (Empire J. Exp. Agric., 8, 65). More than a thousand samples of English malting barley were sent in by growers from the more important barleygrowing districts, grading being carried out by the Valuation Committee of the Institute of Brewing. Six malting grades were distinguished, three for pale-ale and three for mild-ale barleys, the largest number always falling into the latter groups. Spratt Archer and Plumage Archer were by the far the most popular varieties, and their stiffer straws had encouraged generous manuring. Autumn-sown crops usually proved superior in quality but inferior in yield to the spring-sown barleys of the same district and year, and early sowing was generally found to improve the quality in the latter case.

The effect of the crop preceding the barley was also examined. Sugar beet predominated in Norfolk and Suffolk, and in other districts, including Yorkshire, Lincolnshire and the West, folding roots were frequent, whereas elsewhere a cereal crop was more usually taken. Yield was greater after sugar beet or roots than after corn, in spite of the heavier manuring usually given to the straw crop. Lodged crops yielded more than those which were standing, but the quality of the grain was slightly depressed. Analysis was also made of the inter-relationship between soil, season and quality.

\section{Hygiene of Swimming Baths}

IN his inaugural thesis (Thèse de Paris 1940, No. 17), Dr. Marcel Mazillier remarks that it has been known from remote antiquity that certain diseases may be spread by swimming baths, as is shown by the fact that admission to them was forbidden to lepers and others suffering from contagious diseases. The micro-organisms found in the water of bathing places are numerous and of various kinds, the water becoming rapidly contaminated by bacteria derived from the mouth, nose, fæces and urine of the bathers. The diseases contracted in swimming baths chiefly affect the throat, ears and eyes. Cases of spirochætal jaundice, in which the disease may be localized in the meninges, may occur as well as skin diseases, especially that known as 'athletes' foot'. It is therefore important that in constructing a swimming bath care should be taken so far as possible to eliminate causes of contamination, whether derived from the bather himself, who should give himself a douch before entering the bath, the water used for washing out the bath, or other sources. Provision must also be made for the proper heating, ventilating and lighting of the establishment. The drinking water, which must possess all the requisite qualities, may be purified by ultra-violet rays, though this is rather a difficult and expensive process, or by the addition of bactericidal chemical products such as chlorine and its derivatives, colloidal metals and ozone.

\section{Tung Oil}

THE supply of tung oil has been so profoundly affected by the war in China that considerable interest is attached to a report by Dr. M. Ashby upon his tour of the area in the United States in which the tung tree is now being cultivated (Bull. Imperial Inst., 38, No. 1 ; 1940). It is estimated that some 175,000 acres in the States bordering on the Gulf of Mexico now carry plantations of this tree, but many earlier plantations were on land that has since proved unsuitable, the great difficulty proving to be frost damage. The species cultivated is almost exclusively Aleurites fordii Hemsl.

Details are given of cultivation, harvesting and mill treatment of the crop, etc., and it is clear that a very high-grade quality of oil can thus be obtained, but until 1938 the yield had been uncertain owing to frost damage. Although three million pounds of tung oil were produced in the States in 1938 (against an import of 108 millions in that year), until now the paint and varnish industry practically bases itself upon the Chinese supply, though the war has made this a very uncertain source.

\section{Cinchona Production in the Netherland Indies}

AN article by Dr. M. Kerbosch in the Bulletin of the Colonial Institute of Amsterdam (3, No. 1, December 1939) gives some notes on cinchona culture and the world consumption of quinine. Existing plantations in the Netherlands Indies could produce considerably more than the present world consumption. The Netherlands Indies Government has at its disposal sufficient guarantees to prevent the agreement between the manufacturers and producers being used in a way which would hamper malaria control. Cinchona growers would welcome the opportunity to increase their output, and the agreement, which 